\title{
Associations between farming practices and disease mortality of Pacific oyster Crassostrea gigas in a Mediterranean lagoon
}

\author{
Fabrice Pernet ${ }^{1,2, *}$, Franck Lagarde ${ }^{1}$, Patrik Le Gall ${ }^{1}$, \\ Emmanuelle Roque D'Orbcastel ${ }^{1}$
}

\begin{abstract}
${ }^{1}$ Ifremer, Laboratoire Environnement Ressource du Languedoc Roussillon, Bd Jean Monnet, 34200 Sète, France ${ }^{2}$ UMR LEMAR Ifremer/CNRS/UBO/IRD, Technopole de Brest-Iroise, BP 70, 29280 Plouzané, France
\end{abstract}

\begin{abstract}
We present the first large-scale, high-resolution spatial and temporal pattern of disease mortality caused by Ostreid herpesvirus 1 (OsHV-1) that has affected Pacific oyster Crassostrea gigas in France every year since 2008, in relation to local farm use. Mortality was monitored in healthy oyster spat deployed at 106 locations in the Thau Mediterranean lagoon during the epizootic that occurred in spring 2011. We conducted a field survey of farming practices in the areas where the sentinel oysters were placed before the epizootic. We found that the risk of disease mortality in sentinel oysters was higher within the bivalve farming area than outside it, suggesting that the infection pressure is much higher in areas with intensive farming activity. The risk of mortality was higher in farms rearing spat, a developmental stage particularly susceptible to OsHV-1, than in farms rearing adult oysters, which are generally more resistant. Additionally, the mortality risk in farms rearing adult animals was similar to that in empty farms, which suggests that, during the study period, adult oysters did not vector the disease. Interestingly, the mortality risk for sentinel oysters deployed in mussel Mytilus galloprovincialis farms was lower than for those held in oyster farms or empty farms, suggesting that mussels reduced the infection pressure on susceptible oysters.
\end{abstract}

KEY WORDS: Aquaculture $\cdot$ Epidemiology $\cdot$ OsHV-1 $\cdot$ Shellfish farming

\section{INTRODUCTION}

Because it relies directly on natural environments and their trophic resources, bivalve farming is presently facing a number of severe risks and limiting factors. Historically, infectious diseases have seriously affected the marine bivalve industry. Episodes of Pacific oyster Crassostrea gigas mortality have been occurring for more than 5 decades in major oysterproducing countries, such as Japan, the USA and France (Samain \& McCombie 2008). Most of these episodes have been classified as 'summer mortality', typically affecting animals during the warmer months of the year. Since 2008, massive mortality events in

\footnotetext{
*Corresponding author: fabrice.pernet@ifremer.fr
}

C. gigas have been reported in almost all farming areas in France when seawater temperature reaches $16^{\circ} \mathrm{C}$ (EFSA 2010, Pernet et al. 2010b, 2012, 2014, Renault 2011). These mortality events were attributed to the emergence of a particular genotype of ostreid herpesvirus named Ostreid herpesvirus $1 \mu \mathrm{var}$ (OsHV-1; Segarra et al. 2010). Oyster mortalities have been considerable, particularly among seed stocks. Devastation of oyster beds in France every year since 2008 has now resulted in a shortfall of oyster supplies, corresponding to approximately $40 \%$ of commercial production.

The effects of precise farming practices on oyster mortality have not been investigated in sufficient

() The authors 2014. Open Access under Creative Commons by Attribution Licence. Use, distribution and reproduction are unrestricted. Authors and original publication must be credited. 
detail. Indeed, the Morest programme (an Ifremer multidisciplinary research programme run between 2001 and 2006 that aimed to investigate summer mortality in adult oysters in France), examined mortality as a function of characteristics of the 'shellfish farming ecosystem', including temperature, rainfall, primary productivity and distance of oysters from the sediment (Samain \& McCombie 2008). More recently, it was reported that susceptibility to the disease varies with age, origin of oysters, farming practices and life history traits (Dégremont 2011, 2013, Peeler et al. 2012, Pernet et al. 2012, Paul-Pont et al. 2013, 2014, Clegg et al. 2014). Although the effect of aquaculture practices plays an important role in disease transmission and related mortalities (Krkošek 2010), there is a lack of empirical knowledge regarding the mechanisms that trigger disease transmission (Arechavala-Lopez et al. 2013). Most risk assessment studies of disease transmission in aquaculture have been simulated theoretically with limited experimental or in situ testing under farming conditions.

In a companion paper, we explored the spatial and temporal pattern of mass mortality in oysters C. gigas in relation to host energetic reserves and quality of food resources (Pernet et al. 2014). In the present study, disease mortality was investigated in healthy oysters deployed at 106 locations in the Mediterranean Thau lagoon before the start of the epizootic in spring 2011. We found that disease mortality of these 'sentinel' oysters was strongly spatiotemporally dependent, which clearly reflects the epizootic process of local transmission. Also, we showed that oyster disease outbreaks started inside the bivalve farms and spread rapidly beyond them, suggesting that by providing high-density populations of hosts, aquaculture creates conditions suitable for disease epizootics. In this paper, we analysed the role of surrounding farming practices as a risk factor for mortality in sentinel oysters deployed in Thau lagoon. We then examined the potential effect of these farming practices on levels of OsHV-1 and energetic reserves, since these parameters are related to the disease mortality of oysters (Pernet et al. 2014).

\section{MATERIALS AND METHODS}

\section{Study site}

Details of the sentinel oysters, study site, experimental design and laboratory analyses are provided in Pernet et al. (2014). Briefly, the Thau lagoon on the
French Mediterranean coast is an oyster farming area that accounts for ca. $10 \%$ of French Pacific oyster production. The lagoon is $19 \mathrm{~km}$ long, $4.5 \mathrm{~km}$ wide and $5 \mathrm{~m}$ deep on average (Fig. 1). Shellfish are cultured in 3 areas of the lagoon: Bouzigues, Mèze and Marseillan. The lagoon is almost closed off from the Mediterranean Sea, with only a narrow connection through the Sète channel; other connections are negligible in terms of water exchange. In the Thau Lagoon, shellfish are fixed on ropes suspended in the water column from culture tables (Gangnery et al. 2003). Rope length varies between 2 and $6 \mathrm{~m}$ depending on water depth. Tables are $50 \mathrm{~m}$ long, $10 \mathrm{~m}$ wide and divided into 20 squares of $5 \times 5 \mathrm{~m}$. They are made of railway rails pushed into the sediment. These vertical supports hold horizontal iron bars from which ropes of oysters are suspended in the water column. Each table typically supports a total of 1000 ropes on 100 iron bars.

\section{Experimental design}

Diploid oysters were produced at the Ifremer hatchery in La Tremblade in July 2010 and then maintained in the nursery at the Ifremer marine station in Bouin from August 2010 onwards (see Dégremont 2013 for details). The oysters were maintained free of disease mortality from hatching until deployment in the Thau lagoon on 15 March 2011. These oysters had shown no disease mortality prior to deployment, and OsHV-1 DNA was not detected in their tissues (Dégremont 2013). The detection and quantification of OsHV-1 DNA was carried out using a previously published real-time PCR protocol based on SYBR ${ }^{\circledR}$ Green chemistry (Pepin et al. 2008). Mean oyster shell length was $10 \mathrm{~mm}$, mass was $0.7 \mathrm{~g}$ and age was 8 mo. The oysters were placed in 106 pearlnets at an initial density of 150 net $^{-1}$. The pearlnets were deployed in the Thau lagoon, in the farming areas of Bouzigues $(\mathrm{n}=35)$, Mèze $(\mathrm{n}=34)$ and Marseillan $(n=29)$ and also outside of the farming areas $(\mathrm{n}=8)$. The sampling design was primarily developed to capture spatial and temporal trends within the farming areas.

Live and dead oysters were counted in each pearlnet on 31 March; 6, 9, 13, 16, 19, 21, 24, 26 and 29 April; and 3, 6, 10, 13 and 20 May 2011. Soft tissues of 10 pooled individuals were collected from each pearlnet on 6 and 16 April, and stored at $-80^{\circ} \mathrm{C}$ for later quantification of OsHV-1 DNA and energetic reserves (triacylglycerol and carbohydrate), as described elsewhere (Pernet et al. 2012, 2014). The first sampling 


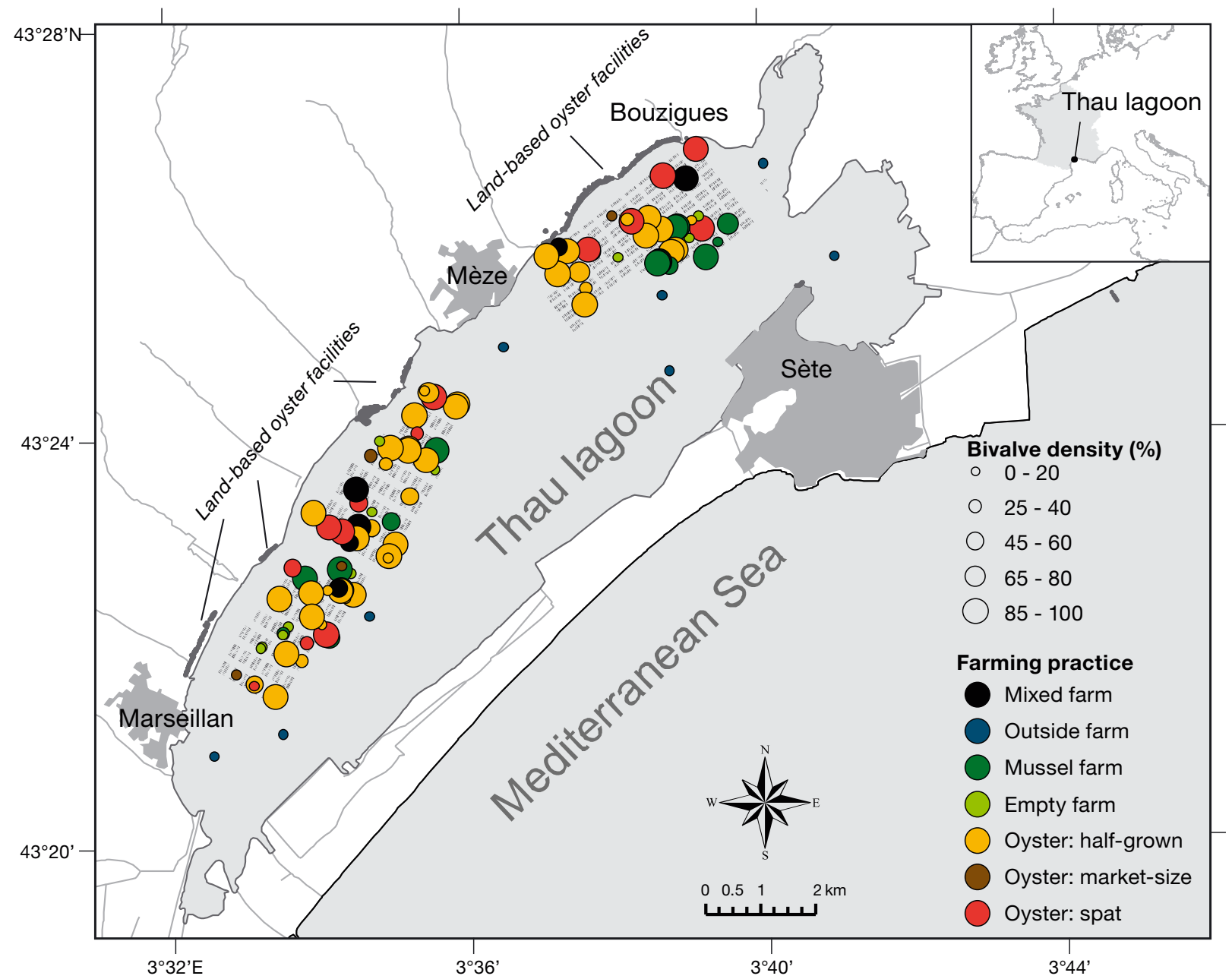

Fig. 1. Farming practices at sampling sites in the Thau lagoon, France. Areas with small grey boxes represent bivalve farms. Oyster: Crassostrea gigas; mussel: Mytilus galloprovincialis

date corresponds to the time of the year when seawater temperature attains $16^{\circ} \mathrm{C}$, a threshold temperature above which disease transmission is optimal and mortalities occur (EFSA 2010, Jolivel \& Fleury 2012, Pernet et al. 2012, 2014, Petton et al. 2013), and the second date corresponds to the date of the onset of the mass mortality (Pernet et al. 2014).

The field survey of farming practices surrounding the sentinel oysters in place was conducted between 1 and 4 April using mobile GIS software designed for field data collection (Trimble ${ }^{\circledR}$ TerraSync ${ }^{\mathrm{TM}}$ ). Farm type and bivalve density were mapped using spatially explicit land registry information interpreted in ArcGIS 10.2 (Fig. 1). Shellfish farms (n = 98) were classified as empty ( $\mathrm{n}=13$ ), used solely to farm mussels (Mytilus galloprovincialis) $(\mathrm{n}=17)$, solely to farm oysters $(\mathrm{n}=64)$ or for both oysters and mussels $(\mathrm{n}=4)$. Oysters were further classed as market-sized ( $>\sim 24$ mo old, shell length $>80 \mathrm{~mm}, \mathrm{n}=4$ ), half grown
(12 to $\sim 24$ mo old, 35-80 mm shell length, $\mathrm{n}=45$ ) or spat ( $<12$ mo old, shell length $<35 \mathrm{~mm}, \mathrm{n}=15$ ), depending on the rearing structure used and animal size. Data and statistics from farms containing both mussels and oysters and farms dedicated to marketsized oysters were not included because the number of samples was too low. Bivalve density was estimated visually, by counting the number of squares occupied by bivalve cultures, and further used as a proxy of bivalve density for each table (number of squares occupied by bivalves out of 20 squares per farm).

\section{Statistics}

Nonparametric estimates of the survivor function were computed by the Kaplan-Meier method (Kaplan \& Meier 1958). Survival time was measured as days from 6 April (time origin), the point when sea- 
water temperature reached $16^{\circ} \mathrm{C}$. The data were read as number of dead animals within each experimental unit at each time interval for 13 intervals. Farm types were used as strata and the resulting survival estimates were compared by using the log-rank test of homogeneity of strata.

The survival time curves of oysters in different sampling areas were compared using the Cox proportional hazards regression model (Cox 1972). The tests on regression parameters were made using the robust sandwich method (Lin \& Wei 1989). Because the exact method for handling ties in failure times uses a considerable amount of computer processing resources, the Efron method was used instead, after replacing each failure time by one selected randomly in the time interval where the event was observed. A sensitivity analysis was done by iterating this process many times and showed a high stability of the regression parameter estimates. The proportionality of hazards was checked by testing the interaction between time and farm type.

Two-way mixed model analyses of covariance (ANCOVAs) were conducted to determine potential differences in quantities of OsHV-1 DNA and energetic reserves of oysters according to farm type, bivalve density and time. The repeated option was applied to the term 'Time' to take into account temporal dependence. Where differences were detected, Fisher's protected LSD multiple comparison tests were used to determine which means were significantly different. Detection frequencies of OsHV-1 DNA in oysters sampled on 6 April were analysed by chi-squared tests of independence according to farm type (6 types $\times 2$ outcomes [not detected / detected]). These statistical analyses were conducted using LIFETEST, FREQ, MIXED and PHREG procedures of the SAS software package (SAS 9.3, SAS Institute).

\section{RESULTS}

Survival analysis of the sentinel oysters deployed in the Thau lagoon is fully described by Pernet et al. (2014). Briefly, we showed that oysters were severely hit by the mass mortality phenomenon (final survival was generally lower than $15 \%$ ) except in the 2 experimental units located in the south-eastern extremity of the lagoon, outside of the farming areas (Pernet et al. 2014). In the present study, we analysed the role of surrounding farming practices as a mortality risk factor for these sentinel oysters.

Farming practices and location within the lagoon influenced the survival of sentinel oysters (log-rank

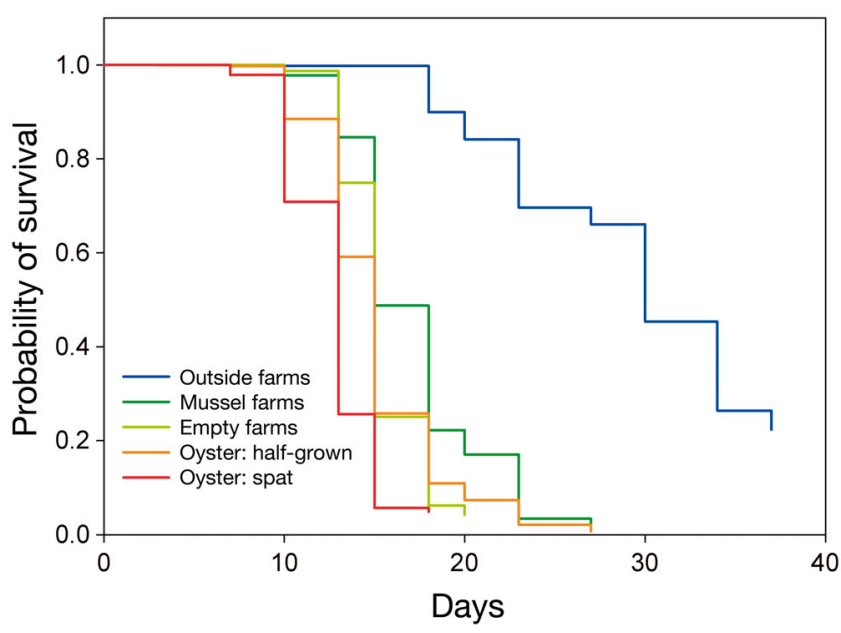

Fig. 2. Survival of sentinel oysters Crassostrea gigas according to farming practices in the Thau lagoon

tests, $\mathrm{p}<0.001$; Fig. 2). Survival time of sentinel oysters, which was computed in days from 6 April (the date when seawater temperature reached $16^{\circ} \mathrm{C}$ ) was only $12.8 \pm 0.06 \mathrm{~d}$ in farms dedicated to oyster spat, $15.1 \pm 0.05 \mathrm{~d}$ in those dedicated to half-grown oysters, $15.3 \pm 0.05 \mathrm{~d}$ in empty farms, $17.2 \pm 0.08 \mathrm{~d}$ in mussel farms and $29.7 \pm 0.28 \mathrm{~d}$ in areas outside of the usual farming zones.

Therefore, farming practices and location within the lagoon influenced the mortality risk factor of the sentinel oysters. The mortality risk for sentinel oysters judged by odds ratios varied from 1.0 (for oysters reared outside of the farming areas used as reference for model parameter calculation) to a maximum of 42.6, and can be ranked as follows:

Spat $>$ empty $=$ half-grown $>$ mussel $>>$ outside farming areas (Table 1).

Bivalve density had no effect on the risk of mortality of oysters, regardless of farm type (data not shown).

Herpesvirus OsHV-1 DNA was detected in 31 experimental units out of 96 on 6 April, when seawater temperature attained $16^{\circ} \mathrm{C}$ (Table 2). The quantity of viral DNA detected in the positive oysters was $3.6 \times 10^{4}$ copy number $\mathrm{mg}^{-1}$ wet tissue (Fig. 3). There was no significant effect of farming practices or location on the detection frequency and quantity of OsHV-1 DNA in oysters $\chi^{2}$ test, $p=0.973$; Fig. 3, Table 3). On 16 April, when the mass mortality event started, OsHV-1 DNA was detected in all experimental units (Table 2), and the quantity of the viral DNA had increased up to $9.0 \times 10^{8}$ copy number $\mathrm{mg}^{-1}$ wet tissue, regardless of farming practices (Fig. 3 , Table 3). 
Table 1. Analysis of the effect of farming practices on survival of oysters Crassostrea gigas in the Thau lagoon by a Cox proportional hazards model. For each farming practice, the following elements are given: its parameter estimate $(\alpha ;$ standard error, $\mathrm{SE}[\alpha])$ and the corresponding instantaneous odds ratio with $95 \%$ CI and the resulting $\mathrm{p}$ value for the type II test from the complete model. Oysters reared outside of the farming areas were used as a reference for model parameter calculation

\begin{tabular}{|lccccc|}
\hline Farming practice & $\alpha$ & $\mathrm{SE}(\alpha)$ & $\begin{array}{c}\text { Odds } \\
\text { ratio }\end{array}$ & $95 \% \mathrm{CI}$ & $\mathrm{p}$ \\
\hline Outside farms & - & - & 1.00 & - & - \\
Mussel farm & 2.300 & 0.064 & 9.97 & $4.1-24.2$ & $<0.001$ \\
Empty farm & 2.863 & 0.067 & 17.51 & $7.1-43.1$ & $<0.001$ \\
Oyster: half-grown & 2.879 & 0.062 & 17.80 & $6.9-45.9$ & $<0.001$ \\
Oyster: spat & 3.751 & 0.067 & 42.56 & $16.6-109.2$ & $<0.001$ \\
\hline
\end{tabular}

Levels of triacylglycerol in oysters sampled on 6 April varied markedly depending on location in the lagoon (Pernet et al. 2014). On average, the level of triacylglycerol in oysters maintained outside the farming areas was double that found in oysters held in the farming areas. Farming practices within the farming area of the lagoon had no influence on the level of triacylglycerol in the sentinel oysters.

Levels of carbohydrate in oysters sampled on 6 April varied depending on location in the lagoon (Pernet et al. 2014) and generally decreased on average by $29 \%$ by 16 April (Fig. 3, Table 3). Differences in farming practices had no clear influence on the level of carbohydrates in the sentinel oysters.

Bivalve density did not influence survival, OsHV-1 DNA frequency and quantity, or energetic reserves of the sentinel oysters.

Table 2. Detection of Ostreid herpesvirus 1 (OsHV-1) DNA according to farming practice and time in oysters Crassostrea gigas deployed in the Thau lagoon. Data are the number of pearlnets containing the sampled oysters $(\mathrm{n}=10$ pooled animals for each analysis)

\begin{tabular}{|c|c|c|c|c|c|c|}
\hline \multirow[t]{3}{*}{ Farming practice } & \multicolumn{6}{|c|}{ OsHV-1 DNA } \\
\hline & \multicolumn{3}{|c|}{-6 April -} & \multicolumn{3}{|c|}{-16 April } \\
\hline & $\begin{array}{c}\text { Not } \\
\text { detected }\end{array}$ & Detected & Sum & $\begin{array}{c}\text { Not } \\
\text { detectec }\end{array}$ & $\begin{array}{l}\text { Detected } \\
\mathrm{d}\end{array}$ & Sum \\
\hline Outside farming areas & 5 & 3 & 8 & 0 & 8 & 8 \\
\hline Sum farming areas & 60 & 28 & 88 & 0 & 92 & 92 \\
\hline Mussel farms & 10 & 5 & 15 & 0 & 15 & 15 \\
\hline Empty farms & 9 & 4 & 13 & 0 & 13 & 13 \\
\hline Oyster: half-grown & 31 & 14 & 45 & 0 & 45 & 45 \\
\hline Oyster: market-size & 2 & 2 & 4 & 0 & 4 & 4 \\
\hline Oyster: spat & 8 & 3 & 11 & 0 & 10 & 10 \\
\hline Sum & 65 & 31 & 96 & 0 & 94 & 94 \\
\hline
\end{tabular}

\section{DISCUSSION}

Here, we provide a large-scale, highresolution spatial and temporal representation of a disease mortality event affecting an economically important marine species, the oyster Crassostrea gigas. The spatial and temporal dynamics of OsHV-1-related mortality of sentinel oysters deployed at 106 locations in the Thau lagoon were analysed in relation to surrounding farming practices. Previous studies on finfish have shown that the use of caged sentinel animals is a promising method for investigating the infection pressure in different coastal areas (Bjørn et al. 2011 and references therein). In our study, mortality risk in sentinel oysters was used as a proxy for infection pressure.

The risk of disease mortality in oysters was higher within the bivalve farming area than outside it. Therefore, it appeared that the infection pressure was considerably increased in areas with farming activity, as previously reported for salmon louse infection (Bjørn et al. 2011). These authors showed that sentinel caged Atlantic salmon smolts held in a non-farmed area had the lowest infection risk, whereas a moderate risk was found in an intermediately farmed area, and an intensively farmed area had the highest infection risk. This result agrees well with the fact that aquaculture, which provides high-density populations of hosts, offers ideal conditions for disease epizootics (McCallum et al. 2004, Krkošek 2010).

The novelty of the present study is that the risk of disease mortality in oysters was investigated not only in relation to the presence or absence of aquaculture farms, but also in relation to the farming practices that characterise bivalve farms. With this approach, we showed that the risk of mortality in sentinel oysters was higher in farms dedicated to spat growing than in farms dedicated to halfgrown oysters. This result is in good agreement with the idea that the infection pressure in an area reflects the density of susceptible hosts (Krkošek 2010), as animals less than $1 \mathrm{yr}$ old are more susceptible to OsHV-1 and showed 

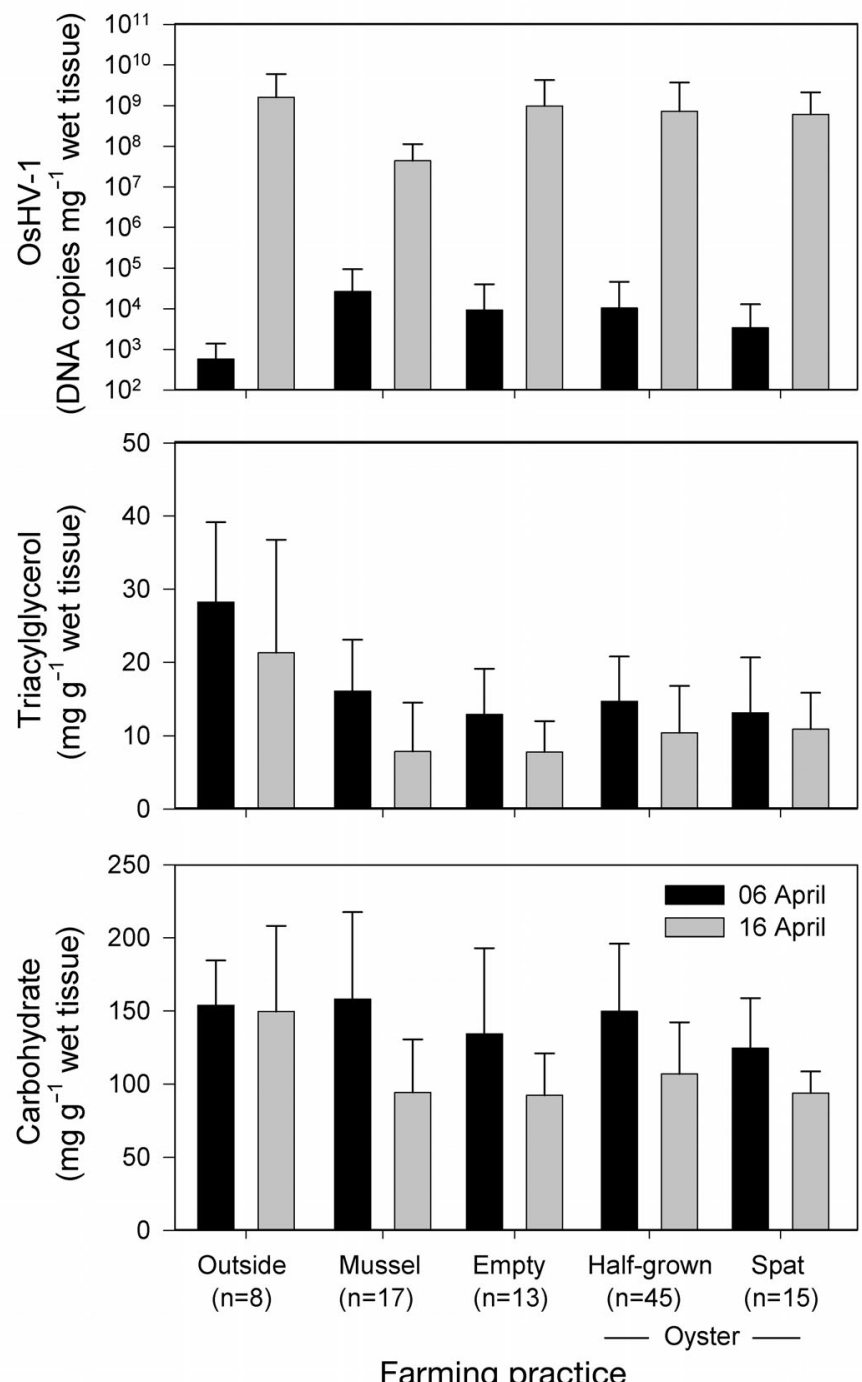

Fig. 3. Ostreid herpesvirus 1 (OsHV-1), triacylglycerol and carbohydrate levels of oysters Crassostrea gigas according to farming practices and time that sentinel oysters were left in place in the Thau lagoon. Data are means + SD of 10 pooled oysters; numbers in parentheses indicate the number of experimental units (or locations) in each category

higher levels of OsHV-1 DNA in their tissues than older ones (Oden et al. 2011, Peeler et al. 2012, Pernet et al. 2012, Paul-Pont et al. 2013).

Also, the risk of mortality in the sentinel oysters held in empty farms was similar to that of farms dedicated to half-grown oysters. Previous studies suggest that adult oysters could act as a reservoir for a variety of pathogens including OsHV-1 $\mu$ var (Arzul et al. 2002, Dégremont et al. 2013). However, 1 yr old oysters living in cohabitation with adults died during the spawning period (Dégremont et al. 2013). It is therefore likely that half-grown oysters act as a reservoir for OsHV-1, but viral shedding and disease transmission to naïve oysters would only occur sporadically, during the spawning period, which generally happens in June in the Thau lagoon. Alternatively, the shedding of viral particles by adult oysters may have been masked by the overall infection pressure in the farming area that occurred in the Thau lagoon during the study period.

In mussel farms, the risk of oyster mortality was lower than in areas dedicated to oyster spat. Here, we hypothesize that, during feeding, mussels bioaccumulate microbes, including oyster pathogens, from the water column. This is supported by the finding that mussels Mytilus edulis modulate the infectious pressure of the cod pathogen Vibrio anguillarum on an integrated multi-trophic aquaculture farm (Pietrak et al. 2012). Viruses and bacteria are too small to be efficiently retained on the gills of most bivalves (Riisgård 1988). When they are attached to particles, however, these microbes are successfully ingested and may represent a significant source of food (see Kach \& Ward 2008 for bacteria). Therefore, if OsHV-1 is attached to particles and aggregates, then mussels may clear OsHV-1 particles from the water column and decrease the infection pressure on susceptible oysters. Despite the fact that OsHV-1 is capable of infecting several bivalve species (Arzul et al. 2001a,b) and OsHV-1 DNA was detected by qPCR in 2009 in apparently healthy mussels M. edulis and M. galloprovincialis, reared near dying oysters in France (T. Renault unpubl. data, as cited in EFSA 2010, Pernet et al. 2010a), the role of mussels as a vector species for OsHV-1 has not been demonstrated.

Mortality of oysters in this study coincided with increasing detection frequency and quantity of OsHV-1 DNA in oyster tissues. Indeed, the risk of oyster mortality in the Thau lagoon was positively correlated with detection of OsHV-1 DNA in oyster tissues (Pernet et al. 2014), which confirms that OsHV-1 is a triggering factor of mass mortality (EFSA 2010, Segarra et al. 2010, Dégremont 2011, Martenot et al. 2011, Oden et al. 2011, Renault 2011, Schikorski et al. 2011a,b, Peeler et al. 2012, Pernet et al. 2012, PaulPont et al. 2013, 2014). However, farming practices had no significant effect on detection frequency and quantity of OsHV-1 DNA in oyster tissues, even though they influenced the mortality risk. This apparently paradoxical result may reflect that OsHV-1 DNA concentration in infected oyster tissues mostly depends on viral replication within the host, which is controlled by the host-cell machinery. Therefore, it cannot be ruled out that farming practices influence the concentration of OsHV-1 in the water column in a way that is correlated with oyster mortality risk. 
Table 3. Results of the 2-way split plot ANCOVAs examining the effects of farming practices: outside vs. inside bivalve farms (mussel, empty, oyster [half-grown, spat]); and time: 6 and 16 April, on quantity of herpesvirus OsHV-1 DNA detected in oyster tissues and their energetic reserves (triacylglycerol and carbohydrate). Occupation rate (density) of farms was used as a covariate. OsHV-1 data were $\log (x+1)$ transformed. Error A: pearlnet (farming practice); Error B: time $\times$ pearlnet (farming practice). Significant $p$-values $(p<0.05)$ are given in bold Num: numerator, Den: denominator

\begin{tabular}{|lrrrr|}
\hline Sources of variation & $\begin{array}{c}\text { Num } \\
\text { df }\end{array}$ & $\begin{array}{r}\text { Den } \\
\text { df }\end{array}$ & $F$ & $p$ \\
\hline OsHV-1 DNA & & & & \\
Farming practice & 4 & 80.4 & 0.18 & 0.9495 \\
Density & 1 & 83.6 & 0.81 & 0.3716 \\
Time & 1 & 81.1 & 118.14 & $<\mathbf{0 . 0 0 0 1}$ \\
Density $\times$ Time & 1 & 83.2 & 0.00 & 0.9461 \\
Farming practice $\times$ Time & 4 & 80.2 & 0.71 & 0.5879 \\
Density $\times$ Farming practice $\times$ Time & 4 & 123.0 & 0.33 & 0.8544 \\
& & & & \\
Triacylglycerol & & & & \\
Farming practice & 4 & 87.2 & 10.19 & $<\mathbf{0 . 0 0 0 1}$ \\
Density & 1 & 90.3 & 0.17 & 0.6747 \\
Time & 1 & 86.8 & 4.80 & $\mathbf{0 . 0 3 1 1}$ \\
Density $\times$ Time & 1 & 89.3 & 0.02 & 0.8782 \\
Farming practice $\times$ Time & 4 & 86.4 & 0.30 & 0.8799 \\
Density $\times$ Farming practice $\times$ Time & 4 & 128.0 & 0.20 & 0.9403 \\
& & & & \\
Carbohydrate & & & & \\
Farming practice & 4 & 84.5 & 2.46 & 0.0514 \\
Density & 1 & 88.6 & 0.88 & 0.3516 \\
Time & 1 & 84.4 & 5.80 & $\mathbf{0 . 0 1 8 2}$ \\
Density $\times$ Time & 1 & 87.3 & 0.12 & 0.7317 \\
Farming practice $\times$ Time & 4 & 83.4 & 0.89 & 0.4724 \\
Density $\times$ Farming practice $\times$ Time & 4 & 127.0 & 0.38 & 0.8192 \\
\hline & & & & \\
\hline
\end{tabular}

in the Thau lagoon farming area (Gangnery et al. 2003). Therefore, it seems that energetic reserves of oysters varied with seston, a parameter not related to local farming practices within the farming area of the Thau lagoon.

\section{CONCLUSION}

This study clearly shows that local differences in farming practices play a significant role in the spatial and temporal dynamics of oyster mortality. In particular, the risk of mortality was higher in areas dedicated to spat, a developmental stage particularly susceptible to OsHV-1, than in farms dedicated to the culture of adult oysters, which are generally more resistant. Also, the mortality risk on farms dedicated to half-grown adult oysters was similar to that on empty farms, which suggests that, during the study period, these adult oysters did not vector the disease. Finally, the mortality risk for oysters on mussel farms was lower than on oyster farms and empty farms, suggesting that mussels reduced the infection pressure. Our study provides a better understanding of factors that contribute to transmission of disease in the aquatic environment, which is necessary to build realistic predictive modelling of disease mortalities.
The level of triacylglycerol in oysters maintained outside the farming areas was twice the levels of those held inside the farming areas, likely reflecting the effect of bivalve farms on food availability. The presence of shellfish farms led to a $\sim 40 \%$ deficit in chlorophyll $a$ in the western part of the Thau lagoon (Souchu et al. 2001). It is therefore likely that oysters held outside of the farming area benefit from more food than those within it, thus enhancing their energetic reserves and their disease resistance (Pernet et al. 2014).

Within the aquaculture area in the Thau lagoon, farming practices had no effect on energetic reserves of sentinel oysters. Energetic reserves of the sentinel oysters varied markedly within the Thau lagoon as a whole and showed a strong spatial dependency, which partly reflects variation in food quality (Pernet et al. 2014) and phytoplankton biomass (P. Gernez \& F. Pernet unpubl. data). Similarly, oyster growth, a parameter which depends on energetics, varies among sites in response to spatial variations in seston
Acknowledgements. We thank Marine Miguet and Julien Vicario for their careful lab work, the staff involved in oyster production (Ifremer hatchery and nursery teams) and Nicolas Keck and Hélène Boulet from the Laboratoire départemental vétérinaire de l'Hérault for OsHV-1 analyses. We also thank Helen McCombie for revising the English version of this manuscript, and 2 anonymous referees. This work was supported by grants from France Agrimer, Région Languedoc-Roussillon and Conseil Général de l'Hérault and is part of the GIGASSAT project funded by ANR-AGROBIOSPHERE No. ANR-12-AGRO0001-01.

\section{LITERATURE CITED}

Arechavala-Lopez P, Sanchez-Jerez P, Bayle-Sempere JT, Uglem I, Mladineo I (2013) Reared fish, farmed escapees and wild fish stocks - a triangle of pathogen transmission of concern to Mediterranean aquaculture management. Aquacult Environ Interact 3:153-161

Arzul I, Nicolas JL, Davison AJ, Renault T (2001a) French scallops: a new host for ostreid herpesvirus-1. Virology 290:342-349

Arzul I, Renault T, Lipart C, Davison AJ (2001b) Evidence 
for interspecies transmission of oyster herpesvirus in marine bivalves. J Gen Virol 82:865-870

Arzul I, Renault T, Thébault A, Gérard A (2002) Detection of oyster herpesvirus DNA and proteins in asymptomatic Crassostrea gigas adults. Virus Res 84:151-160

Bjørn PA, Sivertsgård R, Finstad B, Nilsen R, Serra-Llinares RM, Kristoffersen R (2011) Area protection may reduce salmon louse infection risk to wild salmonids. Aquacult Environ Interact 1:233-244

Clegg TA, Morrissey T, Geoghegan F, Martin SW, Lyons K, Ashe S, More SJ (2014) Risk factors associated with increased mortality of farmed Pacific oysters in Ireland during 2011. Prev Vet Med 113:257-267

Cox DR (1972) Regression models and life tables. J R Stat Soc B Stat Methodol 20:187-220

> Dégremont L (2011) Evidence of herpesvirus (OsHV-1) resistance in juvenile Crassostrea gigas selected for high resistance to the summer mortality phenomenon. Aquaculture 317:94-98

Dégremont L (2013) Size and genotype affect resistance to mortality caused by OsHV-1 in Crassostrea gigas. Aquaculture 416-417:129-134

> Dégremont L, Guyader T, Tourbiez D, Pépin JF (2013) Is horizontal transmission of the Ostreid herpesvirus OsHV-1 in Crassostrea gigas affected by unselected or selected survival status in adults to juveniles? Aquaculture 408-409:51-57

EFSA (European Food Safety Authority Panel on Animal Health and Welfare) (2010) Scientific opinion on the increased mortality events in Pacific oysters, Crassostrea gigas. EFSA J 8:1894-1953

Gangnery A, Chabirand JM, Lagarde F, Gall PL, Oheix J, Bacher C, Buestel D (2003) Growth model of the Pacific oyster, Crassostrea gigas, cultured in Thau Lagoon (Méditerranée, France). Aquaculture 215:267-290

Jolivel A (2012) Analyse statistique des données de mortalité d'huîtres acquises par l'Observatoire National Conchylicole (RESCO). Master's thesis II, Rennes 2 Agrocampus Ouest, Rennes (in French)

Kach DJ, Ward JE (2008) The role of marine aggregates in the ingestion of picoplankton-size particles by suspension-feeding molluscs. Mar Biol 153:797-805

> Kaplan EL, Meier P (1958) Nonparametric estimation from incomplete observations. J Am Stat Assoc 53:457-481

Krkošek M (2010) Host density thresholds and disease control for fisheries and aquaculture. Aquacult Environ Interact 1:21-32

> Lin DY, Wei LJ (1989) The robust inference for the proportional hazards model. J Am Stat Assoc 84:1074-1078

> Martenot C, Oden E, Travaille E, Malas JP, Houssin M (2011) Detection of different variants of Ostreid Herpesvirus 1 in the Pacific oyster, Crassostrea gigas between 2008 and 2010. Virus Res 160:25-31

> McCallum HI, Kuris A, Harvell CD, Lafferty KD, Smith GW, Porter J (2004) Does terrestrial epidemiology apply to marine systems? Trends Ecol Evol 19:585-591

> Oden E, Martenot C, Berthaux M, Travaillé E, Malas JP, Houssin M (2011) Quantification of ostreid herpesvirus 1 (OsHV-1) in Crassostrea gigas by real-time PCR: determination of a viral load threshold to prevent summer mortalities. Aquaculture 317:27-31

Paul-Pont I, Dhand NK, Whittington RJ (2013) Influence of husbandry practices on OsHV-1 associated mortality of Pacific oysters Crassostrea gigas. Aquaculture 412-413: 202-214

> Paul-Pont I, Evans O, Dhand NK, Rubio A, Coad P, Whittington RJ (2014) Descriptive epidemiology of mass mortality due to Ostreid herpesvirus-1 (OsHV-1) in commercially farmed Pacific oysters (Crassostrea gigas) in the Hawkesbury River estuary, Australia. Aquaculture 422-423: 146-159

> Peeler EJ, Reese RA, Cheslett DL, Geoghegan F, Power A, Thrush MA (2012) Investigation of mortality in Pacific oysters associated with Ostreid herpesvirus-1 $\mu$ Var in the Republic of Ireland in 2009. Prev Vet Med 105:136-143

$>$ Pepin JF, Riou A, Renault T (2008) Rapid and sensitive detection of ostreid herpesvirus 1 in oyster samples by real-time PCR. J Virol Methods 149:269-276

Pernet F, Barret J, Gall PL, Malet N and others (2010a) Mortalité du naissain d'huître creuse Crassostrea gigas dans l'étang de Thau en 2009. Ifremer, available at http://archimer.ifremer.fr.doc/00002/11354/ (in French)

> Pernet F, Barret J, Marty C, Moal J, Le Gall P, Boudry P (2010b) Environmental anomalies, energetic reserves and fatty acid modifications in oysters coincide with an exceptional mortality event. Mar Ecol Prog Ser 401: 129-146

Pernet F, Barret J, Le Gall P, Corporeau C and others (2012) Mass mortalities of Pacific oysters Crassostrea gigas reflect infectious diseases and vary with farming practices in the Mediterranean Thau lagoon, France. Aquacult Environ Interact 2:215-237

Pernet F, Lagarde F, Jeannée N, Daigle G and others (2014) Spatial and temporal dynamics of mass mortalities in oysters is influenced by energetic reserves and food quality. PLoS ONE 9:e88469

Petton B, Pernet F, Robert R, Boudry P (2013) Temperature influence on pathogen transmission and subsequent mortalities in juvenile Pacific oysters Crassostrea gigas. Aquacult Environ Interact 3:257-273

> Pietrak MR, Molloy SD, Bouchard DA, Singer JT, Bricknell I (2012) Potential role of Mytilus edulis in modulating the infectious pressure of Vibrio anguillarum $02 \beta$ on an integrated multi-trophic aquaculture farm. Aquaculture 326-329:36-39

Renault T (2011) A review of mortality outbreaks in the Pacific oyster, Crassostrea gigas, reported since 2008 in various European Union Member States and the related implementation of Council Directive 2008/88/EC. Bull OIE 4:51-52

Riisgård HU (1988) Efficiency of particle retention and filtration rate in 6 species of Northeast American bivalves. Mar Ecol Prog Ser 45:217-223

Samain JF, McCombie H (eds) (2008) Summer mortality of Pacific oyster Crassostrea gigas, the Morest project. Ifremer/Quæ Éditions, Versailles

Schikorski D, Faury N, Pepin JF, Saulnier D, Tourbiez D, Renault T (2011a) Experimental ostreid herpesvirus 1 infection of the Pacific oyster Crassostrea gigas: kinetics of virus DNA detection by q-PCR in seawater and in oyster samples. Virus Res 155:28-34

Schikorski D, Renault T, Saulnier D, Faury N, Moreau P, Pepin JF (2011b) Experimental infection of Pacific oyster Crassostrea gigas spat by ostreid herpesvirus 1: demonstration of oyster spat susceptibility. Vet Res 42:27

> Segarra A, Pepin JF, Arzul I, Morga B, Faury N, Renault T (2010) Detection and description of a particular Ostreid herpesvirus 1 genotype associated with massive mortality outbreaks of Pacific oysters, Crassostrea gigas, in France in 2008. Virus Res 153:92-99

Souchu P, Vaquer A, Collos Y, Landrein S, Deslous-Paoli JM, Bibent B (2001) Influence of shellfish farming activities on the biogeochemical composition of the water column in Thau lagoon. Mar Ecol Prog Ser 218:141-152 